\title{
PHET Simulation sebagai Alat Bantu Siswa Sekolah Dasar dalam Proses Belajar Mengajar Mata Pelajaran Matematika
}

\author{
Sisilia Sylviani ${ }^{1}$, Fahmi Candra Permana ${ }^{2}$, Rio Guntur Utomo ${ }^{3}$ \\ 1) Departemen Matematika, FMIPA, Universitas Padjadjaran \\ Jl. Raya Bandung-Sumedang Km. 21, Jatinangor 45363 \\ Email: sisilia.sylviani@unpad.ac.id \\ 2) Program Studi Pendidikan Multimedia, Kampus UPI di Cibiru, Universitas Pendidikan Indonesia \\ Jl. Raya Cibiru Km 15 Bandung 40393 \\ Email: fahmi.candrap@upi.edu \\ 3) School of Electronics and Computer Science, University of Southampton \\ Southampton, United Kingdom \\ Email: rgu1n15@soton.ac.uk
}

\begin{abstract}
ABSTRAK
Dalam paper ini dibahas penggunaan PhET Simulation sebagai alat bantu dalam kegiatan belajar mengajar matematika khususnya materi pecahan. PhET Simulation merupakan simulasi yang dapat digunakan oleh guru dalam mengajarkan materi pecahan di kelas. Dengan menggunakan PhET Simulation, siswa akan terlibat secara aktif dalam proses berpikir dan mengambil kesimpulan. PhET Simulation juga membuat materi yang dipelajari menjadi lebih menarik dan terlihat "nyata". Dengan demikian, siswa dapat lebih tertarik dalam pembelajaran materi ini yang pada akhirnya akan memudahkan siswa dalam memahami materi tersebut.
\end{abstract}

Kata kunci: matematika, pecahan, simulasi

\begin{abstract}
This paper discusses the use of PhET Simulation as a tool in mathematics teaching and learning activities, especially in fraction material. PhET Simulation is a simulation that can be used by teachers in teaching fraction material in class. By using PhET Simulation, students will be actively involved in the process of thinking and drawing conclusions. PhET Simulation also makes the material being studied more interesting and looks "real". Thus, students can be more interested in learning this material which will ultimately make it easier for students to understand the material.
\end{abstract}

Keywords: fraction, mathematics, simulation

\section{Pendahuluan}

Matematika merupakan salah satu mata pelajaran yang wajib yang sering ditakuti oleh para siswa. Mata pelajaran tersebut seringkali dirasakan abstrak oleh para siswa (sylviani, 2019). Salah satu topik yang dipelajari siswa sekolah dasar dalam mata pelajaran adalah pecahan. Materi pecahan merupakan salah satu materi yang terus akan digunakan bahkan hingga siswa tersebut menempuh Pendidikan di Perguruan inggi atau bahkan hingga bekerja. Konsep pecahan tersebut terlihat sederhana bahkan terkadang guru hanya memberikannya tidak terlalu mendalam. Hingga siswa tidak memahaminya secara mendalam. Akibatnya, siswa bisa saja mapu memecahkan permasalahn tertentu pada saat siswa tersebut sedang mempelajari materi pecahan, namun dengan beranjaknya waktu hal tersebut sering kali dilupakan oleh siswa atau bahkan siswa memang belum terlalu paham secara mendalam, hanya mampu mengoperasikan rumus-rumus matematikanya. Banyak dosen yang mengeluhkan bahwa beberapa mahasiswa yang mereka temui bahkan tidak dapat menyelesaikan permasalahan pecahan sederhana yang seharusnya telah mereka dapatkan di sekolah dasar. Oleh karena itu, kiranya perlu dilakukan evaluasi terhadap proses belajar mengajar yang selama ini telah dilakukan di kebanyakan sekolah. Hendaknya siswa tidak hanya dilatih untuk menjadi "kalkulator", tetapi juga siswa dilatih untuk mempunyai kemampuan berpikir yang lebih dalam, tentunya sesuai tingkatan jenjang sekolahnya.

Berbagai upaya telah banyak dilakukan oleh para peneliti untuk mengatasi kendala tersebut. Ada yang menggunakan Teknik mengajajar dengan pendekatan tertentu ataupun ada yang menggunakan alat bantu sebagai media pembelajaran. Di era digital saat ini, hampir dalam setiap aspek keidupan kita mennggunakan 
hal-hal yang berbau digital. Bahkan saat ini terdapat beberapa peneliti yang menghubungkan hal-hal yang bersifat kerifan local dengan dunia digital, salah satunya yang dilakukan oleh permana (2019). Dalam dunia Pendidikan, simulasi komputer edukasional telah banyak digunakan oleh banyak pengajar matematika serta merupakan alat yang cukup menjanjikan dalam menunjukkan efektifitasnya dalam membantu meningkatkan pemahaman siswa dalam mempelajari konsep-konsep matematika. Banyak pengajar yang mengembangkan metode pengajaran dengan menggunakan alat bantu simulasi komputer. Dalam paper ini akan dibahas penggunaan PhET Simulation sebagai alat bantu dalam kegiatan belajar mengajar dalam mata pelajaran matematika khususnya untuk materi pecahan pada siswa sekolah dasar.

\section{Metode Penelitian}

Dalam penelitian ini, metodologi penelitian yang digunakan adalah studi literatur dari berbagai sumber baik bukubuku ataupun jurnal-jurnal. Buku-buku digunakan untuk menyesuaikan kurikulum yang digunakan di Sekolah Dasar sebagai dasar dalam merancang latihan terstruktur untuk siswa. Jurnal-jurnal digunakan sebagai referensi hal-hal terbaru terkait PhET Simulation yang dapat digunakan dan dikembangkan dalam penelitian ini. Secara rinci hal yang pertama dilakukan oleh penulis adalah dengan melakukan tinjauan lebih dalam terkait PhET Simulation. Adapaun hal yang ditinjau lebih dalam adalah fitur-fitur yang ada dalam PhET Simulation yang dapat digunakan serta digunakan dalam penelitian ini. Hal yang selanjutnya dilakukan adalah mencari materi yang tepat dimana PhET simulation dapat digunakan di dalamnnya. Selanjutnya adalah merancang latihan terstruktur yang dapat digunakan di kelas berdampingan dengan PhET simulation.

\section{Tentang PHET Simulation}

PhET Simulation merupakan kependekan dari the physics Education Technology. PhET Simulation menyediakan simulasi-simulasi komputer interaktif matematika dan sains berbasis penelitian yang interaktif, menyenangkan dan gratis yang dapat digunakan untuk meningkatkan keefektifan pengajaran dan pembelajaran matematika. PhET Simulation tersedia secara gratis dari situs web PhET Simulation (http://PhET.colorado.edu). Simulasi-smulasi tersebut dalam bentuk animasi dan interaktif serta seperti permainan, sehingga siswa belajar melalui eksplorasi. PhET Simulation dapat digunakan langsung secara online ataupun dapat diunduh terlebih dahulu baru kemudian digunakan secara offline. Salah satu tujuan dari PhET Simulation adalah menyediakan media yang terbuka yang dapat digunakan oleh para siswa untuk bereksplorasi pada saat mempelajari konsep-konsep tertentu. Simulasi yang terdapat di PhET Simulation, sesuai dengan namanya, mayoritas merupakan simulasi-simulasi yang terkait konsep-konsep yang dipelajari pada Fisika. Namun demikian, PhET Simulation juga menyediakan sejumlah simulasi yang terkait dengan konsep-konsep yang dipelajari di Kimia, matematika, dan sains kebumian dan masih terus bertambah serta dikembangkan. Berikut ini adalah tampilan muka dari PhET simulation, khusus untuk simulasi matematika.

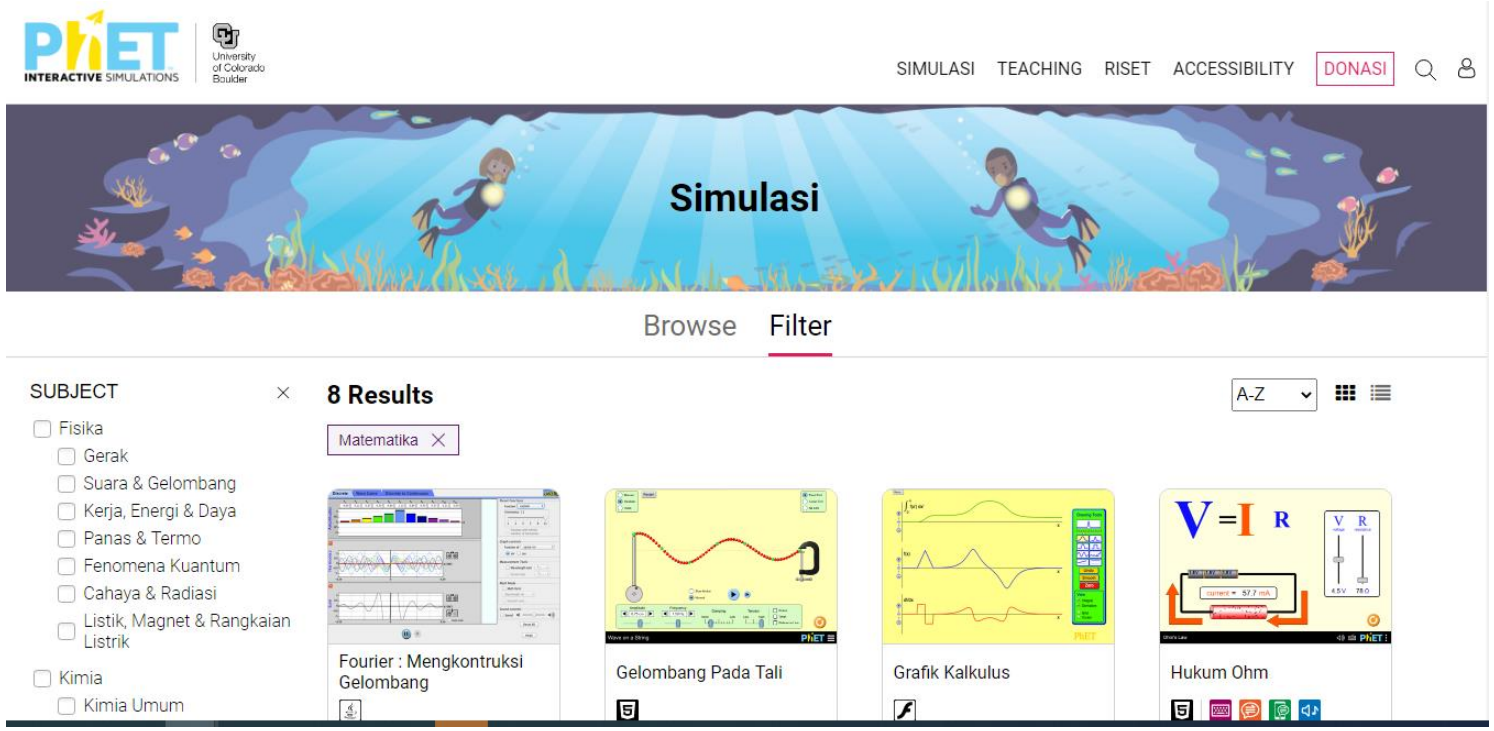

Gambar 1. Tampilan muka PhET Simulation untuk simulasi matematika 
PhET Simulation juga telah memenangkan banyak penghargaan. Seperti dilansir oleh tim PhET simulation pada laman web nya, penghargaan tersebut adalah Open Education Award for Excellence: Open Simulation (2019), TPG Web Accessibility Challenge, Delegates Award (2018), APS Excellence in Physics Education Award (2018) WISE Awards (2017), SIGOL Online Learning Award, 2nd place (April 2012), Tech Award and Microsoft Education Award (October 2011), NSF \& Science Magazine's International Science \& Engineering Visual Challenge award (2007), MERLOT Classics Award in Physics (2006), dan MERLOT Editor's Choice Award (2006) (PhET on MERLOT).

Di sisi lain, PhET Simulation didesain untuk memantu siswa terlibat dalam sains dan matematika melalui penyelidikan. PhET Simulation juga dibangun dengan menggunakan prinsip-prinsip desain sebagai berikut: mendorong penyelidikan secara ilmiah, menyediakan interaktivitas, membuat yang semula terlihat menjadi terlihat, menyertakan beberapa representasi (Gerakan objek, grafik, angka, dll), menggunakan koneksi dengan dunia nyata, memberikan panduan implisit kepada pengguna (mis., dengan membatasi kontrol) dalam eksplorasi yang produktif, dan membuat simulasi yang dapat digunakan secara fleksibel dalam banyak situasi Pendidikan.

Terkait prinsip desain dari PhET Simulation yang salah satunya adalah dengan mengusung penyediaan media yang interaktif, terdapat beberapa alat atau tools yang disediakan untuk mendukung hal tersebut. Alatalat tersebut diantaranya adalah click dan drag yang dapat digunakan untuk berinteraksi dengan fitur-fitur yang ada dalam simulai PhET Simulation. Sliders yang dapat digunakan menaikkan atau menurunkan parameter. Tombol radio yang dapat digunakan untuk memilih diantara beberapa pilihan. Beberapa intstrumen seperti penggaris stop watch, voltmeter, dan thermometer juga tersedia di dalam simulasi yang dapat digunakan untuk melakukan pengukuran. Saat pengguna berinteraksi dengan alat-alat tersebut, mereka mendapatkan umpan balik secara langsung tentang efek dari perubahan yang mereka buat. Ini memungkinkan mereka untuk menyelidiki hubungan sebab-akibat dan menjawab pertanyaan ilmiah melalui eksplorasi simulasi.

Keistimewaan lainnya adalah PhET simulation juga menyediakan berbagai pilihan Bahasa penggunga yang dapat digunakan. Dengan demikian, untuk pengguna yang memiliki kendala dalam Bahasa inggris, masih dapat menggunakan aplikasi ini dengan baik karena di dalamnya tersedia banyak piliha Bahasa yang dapat digunakan. Hal lain yang juga menjadikan PhET Simulation istimewa adalah team pembangun PhET Simulation selalu melakukan penelitian untuk mengetes bagaimana simulasi-simulasi dalam PhET Simulation bekerja. Mereka melakukan tes secara berulang untuk mengetahui kekurangan apa yang ada pada simulasi-simulasinya tersebut dan kemudian memperbaiki kekurangannya tersebut.

\section{Strategi untuk Implementasi PhET Simulation di ruang kelas}

Dalam menerapkan PhET Simulation sebagai alat bantu dalam kegiatan belajar mengajar di kelas, memerlukan strategi atau prosedur dalam penggunaannya. Perkins, dkk., 2012 mengemukakan bahwa strategi yang dapat dilakukan di ruang kelas adalah sebagai berikut:

1. Scientific Process Skill, keterlibatan siswa pada saat eksplorasi, mengajukan pertanyaan, membuat hipotesis, mengumpulkan bukti, dan mengontrol variable.

2. Evidence-based reasoning, siswa mengumpulkan dan menggunakan bukti untuk membuat argumentasi saintifik dan mengambarkan solusi

3. Abstract thinking, siswa belajar dan menggunakan abstraksi

4. Representasi, siswa belajar, mengkoordinasikan, menggunakan beberapa representasi

5. Measurement, siswa menggunakan alat ukur seperti penggaris

6. Communication and argumentation, siswa terlibat dalam argumentasi saintifik dengan siswa lain dan pengajar

7. Affect, siswa dapat merasakan bahwa matematika dapat menjadi sesuatu yang menyenangkan bagi mereka

Ketujuh strategi tersebut terangkum dalam Langkah-langkah berikut ini.

Langkah pertama : memberikan waktu sekitar 10-20 menit untuk siswa dapat bermain secara bebas dengan PhET Simulation sebelum memberikan pertanyaan tertentu. Dalam hal ini guru dapat meminta siswa membuat kelompok kecil Bersama temannya. Kemudian mereka diminta untuk mengeksplorasi serta berdiskusi dengan temannya terkait simulasi pembagian. Perhatikan tampilan antar muka dari simulasi pembagian "Basic" pada gambar berikut. 


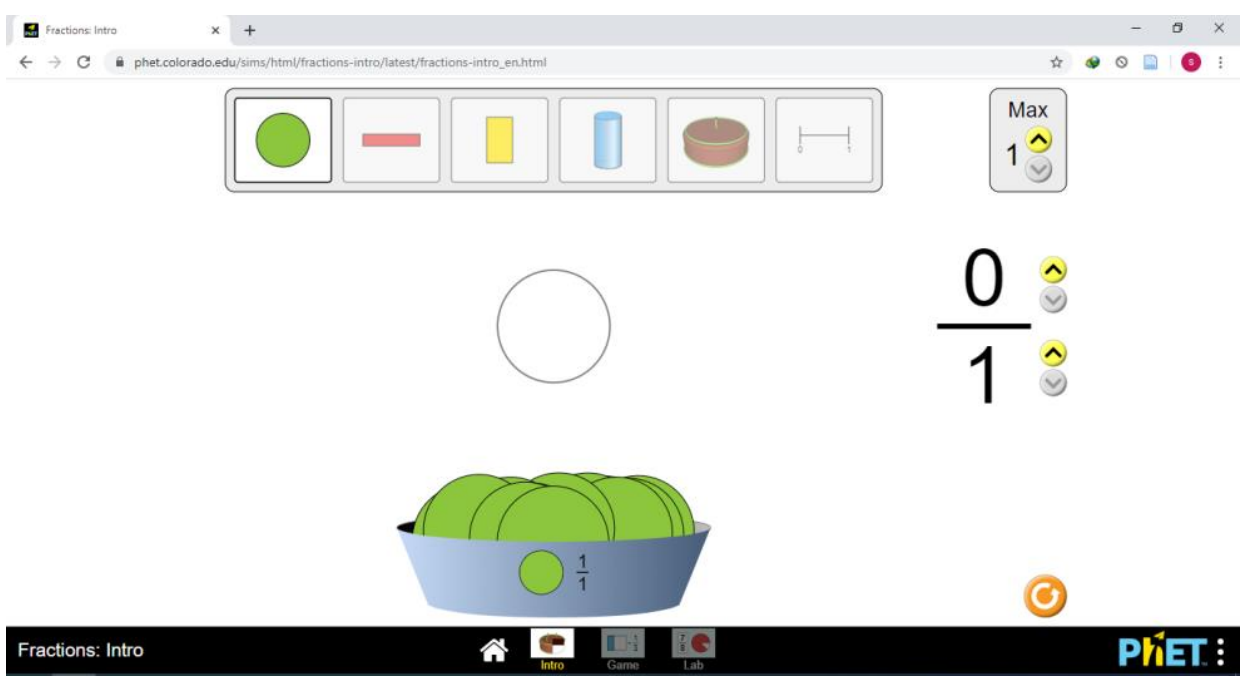

Gambar 2. Tampilan awal simulasi "pecahan"

Hal yang perlu diperhatikan pada tahap ini adalah pengajar hanya memberikan panduan bagaimana membuka aplikasi atau mengarahkan siswa pada laman web yang dituju. Pengajar dapat pula membuka terlebih dahulu aplikasi atau laman web yang di maksud apabila simulasi dilakukan di laboratorium. Sehingga pada saat simulasi akan dilakukan, siswa sudah disediakan aplikasi simulasinya. Selebihnya, yang dilakukan adalah membiarkan siswa untuk mengeksplorasi hal baru yang ada di hadapan mereka.

Pada masa ini,siswa mulai mencoba-coba hal yang ada di hadapan mereka. Mereka yang baru melihat simulasi tersebut pada awalnya akan melakukan coba-cobal click ini dan itu. Mereka dibiarkan untuk mempelajari sendiri bagaimana cara kerja dari PhET simulation ini. Misalkan pada simulasi tentang pecahan. Dari gambar yang ditampilkan pada gambar 3 di bawah ini, terlihat terdapat beberapa bentuk berwarna warni serta angka-angka dan juga tools lainnya. Salah satu hal yang dapat mereka lakukan di awal adalah dengan meng-click gambar lingkaran berwarna hijau, kemudian melihat apa yang akan terjadi. Setelah itu mereka akan beranjak untuk meng-click gambar persegi berwarna merah muda, dan seterusnya hingga gambar garis dengan batas 0 dan 1 . Hal yang dapat terjadi adalah mereka dapat melihat perubahan yang terjadi saat mereka meng-click tombol-tombol tersebut, namun mereka belum memahami fungsinya. Mereka juga dapat meng-click tombol panah atas bawah dan melihat apa yang terjadi. Seperti halnya yang dilakukan sebelumnya, siswa baru dapat melihat perubahan yang terjadi, namun kemungkinan belum terlalu memahami fungsinya.

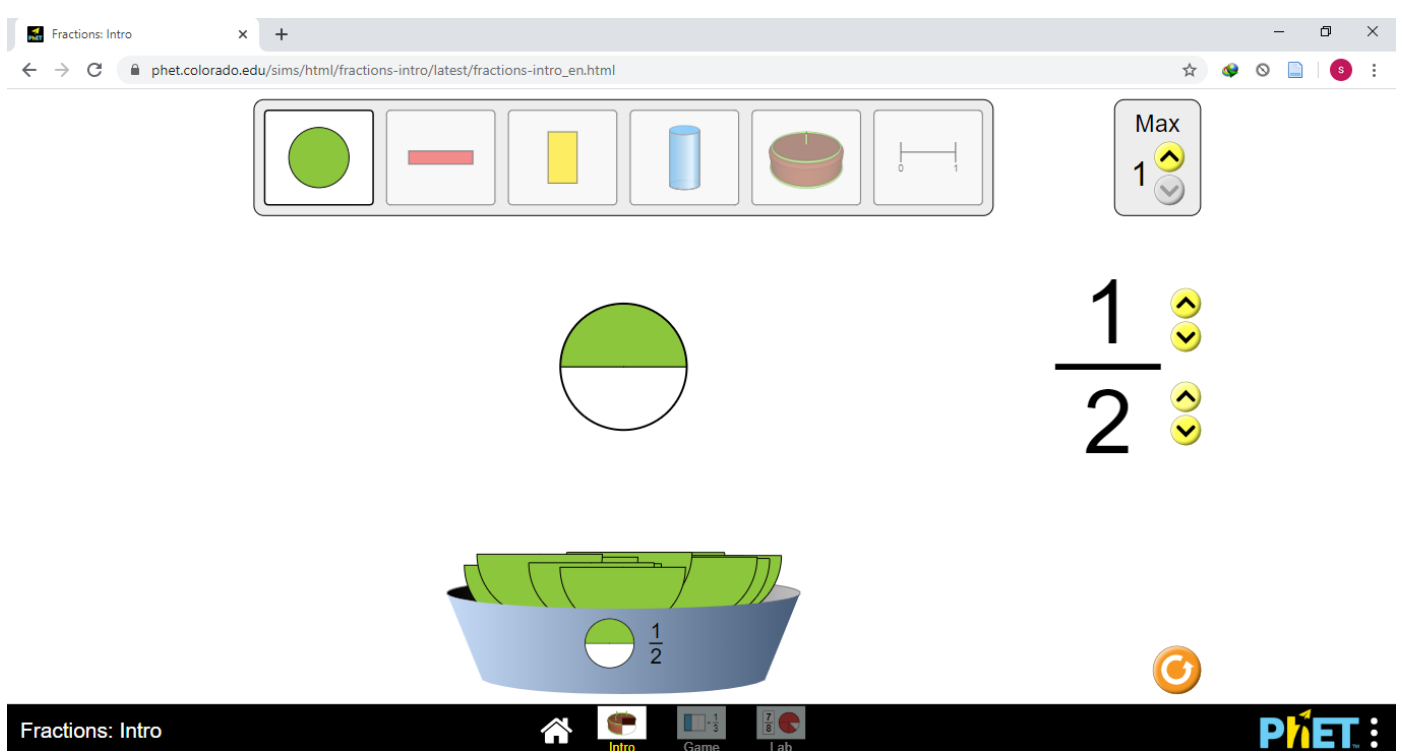

Gambar 3. Salah satu percobaan yang dapat dilakukan siswa 
Mereka dapat melakukan coba-coba merubah angka-angka yang terdapat pada pecahan yang mereka lihat di layar. Mereka dapat melihat bahwa dengan mengubah angka pada kota "max" artinya adalah mengubahangka maksimum dari hasil pecahan tersebut. Di sisi lain, untuk mengubah angka-angka pembilang dan penyebut pada pecahan tersebut, siswa cukup menggunakan tanda panah yang ada di sampingnya. Pada saat mereka mencoba untuk mengubah angka-angka pembilang dan penyebut dari pecahan tersebut, mereka dapat melihat bahwa gambar yang ada di sampingnya juga ikut berubah. Dari proses ini mereka dapat melihat bahwa gambar di samping pecahan merupakan representasi dari pecahan tersebut. Perhatikan gambar 4 berikut sebagai contoh simulasi yang dilakukan untuk pecahan 3/8.

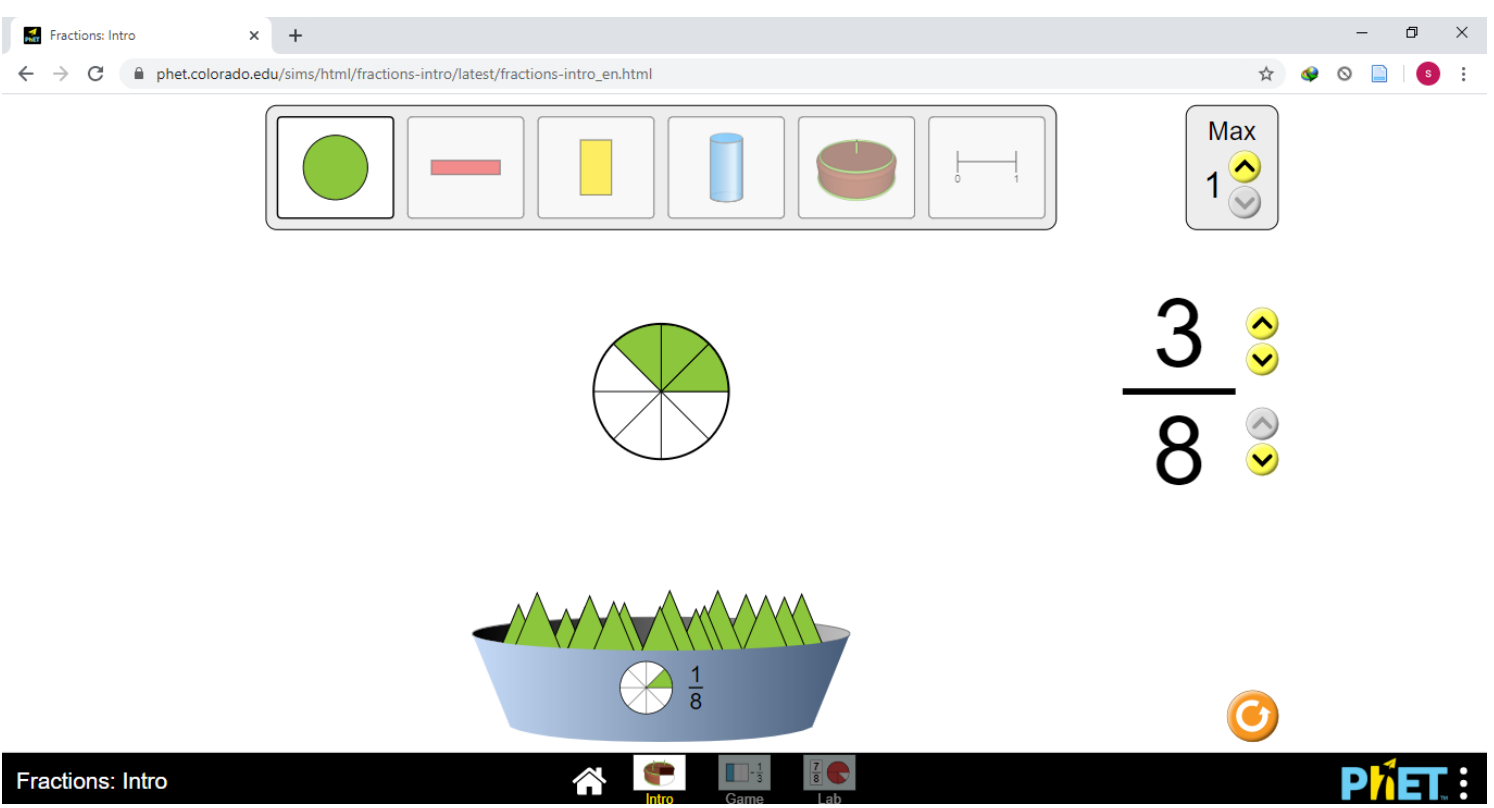

Gambar 4. Percobaan mengubah angka

Percobaan di atas dilakukan untuk nilai maksimum pecahannya 1. Pada saat siswa mengubah angka pada kotak "max", mereka juga akan melihat bahwa jumlah dari lingkaran berubah menjadi sebanya angka yang tertera pada kotak "max" tersebut. Gambar 5 memperlihatkan contoh apabila angka pada kotak "max" diubah menjadi 6. Hal yang terjadi adalah lingkaran yang ada pada gambar berubah menjadi 6. Mereka juga dapat mengubah angka pecahan. Dalam hal ini penulis mengambil contoh representasi untuk 18/8.
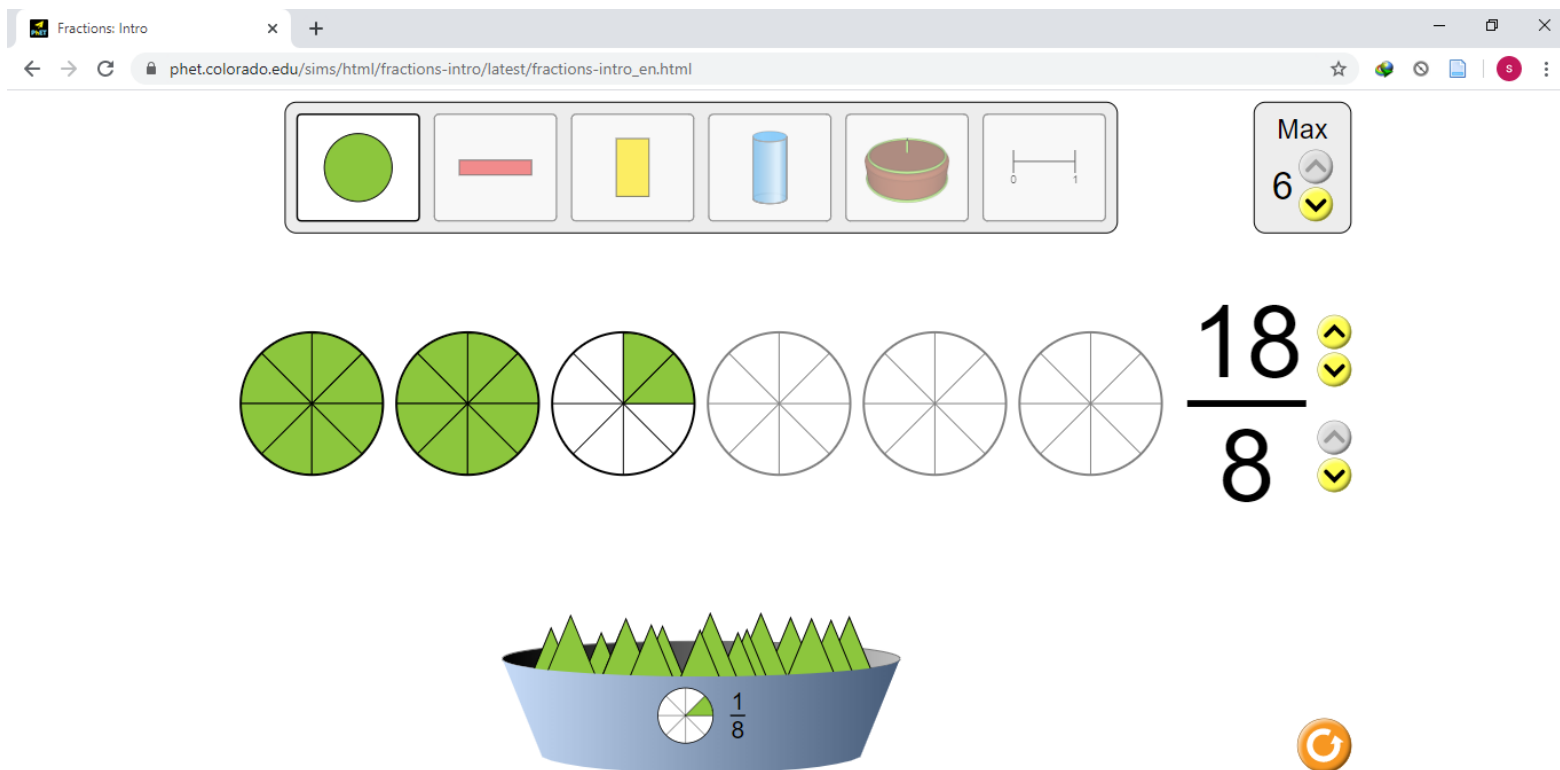
Selain angka yang direpresentasikan dengan gambar, hal sebaliknya juga dapat dilakukan. Siswa dapat meng-click gambar lingkaran kecil yang terdapat pada wadah yang memuat bagian-bagian dari lingkaran yang berwarna hijau. Dengan mendrag gambar lingkaran tersebut menuju gambar linkaran besar yang ada di atasnya, maka seolah-olah siswa sedang memasukan satu bagian lingkaran yang berwarna hijau dan memasangkannya ke dalam bagian lingkaran yang berwarna putih. Ini artinya, mereka dapat megubah gambar dari potongan atau irisan lingkaran tersebut. Hal lain yang dapat mereka lihat pada saat melakukan hal ini adalah bahwa angka pecahan di sampingnya juga ikut berubah.

Selanjutnya, hal yang dapat mereka lakukan adalah dengan meng-click gambar pesegi berwarna merah. Misalnya hal tersebut dilakukan setelah mereka melakukan percobaan merepresentasi pecahan 18/8. Mereka dapat melihat bahwa yang terjadi apabila gambar persegi merah tersebut adalah gambar irisan-irisan dari persegi panjang berwarna merah yang menggambarkan pecahan 18/8 tersebut. Hal tersebut dapat dilihat pada gambar 6 di bawah ini.
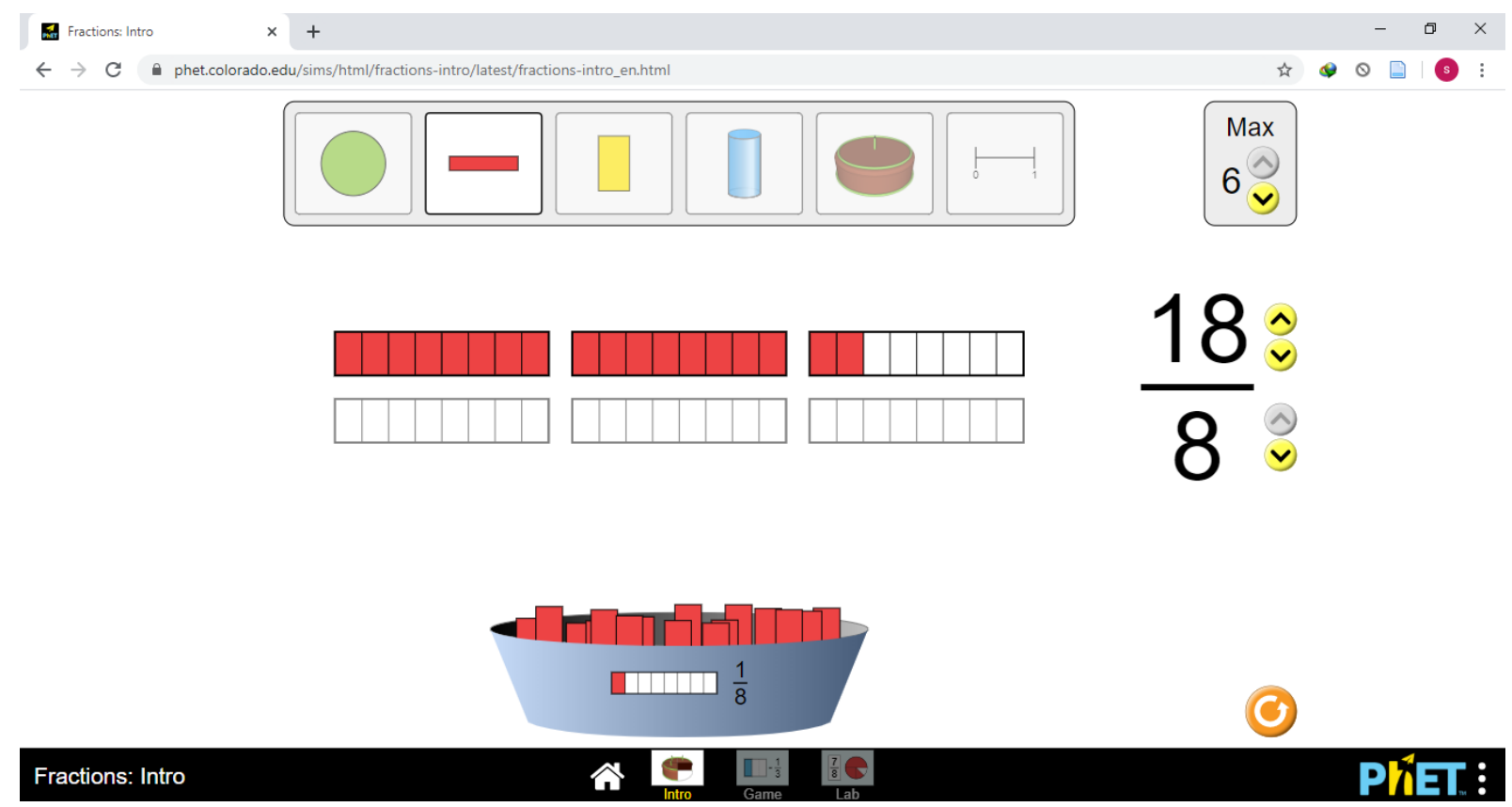

Gambar 6. Percobaan mengubah pilihan bentuk

Apabila mereka meng-click gambar persegi panjang berwarna kuning gambar serupa akan keluar, hanya saja persegi yang ditampilkan dalam posisi vertical dengan bagian-bagian yang berwarna kuning. Selanjutnya, apabila mereka meng-click gambar tabung berwarna biru, hal yang ditampilkan adalah seperti tabung ukur dengan isi air yang berwarna biru. Air yang berada dalam tabung tersebut merepresentasikan nilai pecahan yang ada di sampingnya. Kemudian, dengan meng-click gambar kue ulang tahun berwarna coklat, mereka dapat melihat hal serupa, yaitu bahwa kue ulang tahun tersebut juga merepresentasikan pecahan yang ada di sampingnya. Dalam hal ini mungkin saja gambar kue ulang tahun ini menjadi gambar yang paling disenangi oleh siswa untuk digunakan dalam merepresentasikan pecahan. Bentuk terakhir yang ada di simulasi tersebut yang dapat digunakan sebagai representasi atau gambaran dari pecahan tersebut adalah garis bilangan. Terdapat sedikit perbedaan antara gambar ini dengan gambar-gambar lainnya. Pada gambargambar sebelumnya, yang dilakukan untuk mengubah gambar adalah dengan men-drag bagian-bagian yang ada pada wadah. Sedangkan di sini siswa daoat menggeser-geser lingkaran kecil berwarna hijau yang terdapat pada garis bilangan tersebut dan melihat apa yang terjadi. Gambar ini juga merupakan gambar yang terlihat "lebih matematis" dalam menggambarkan pecahan tersebut. Ada kemungkinan gambar ini merupakan gambar yang sedikit diminat siswa. 


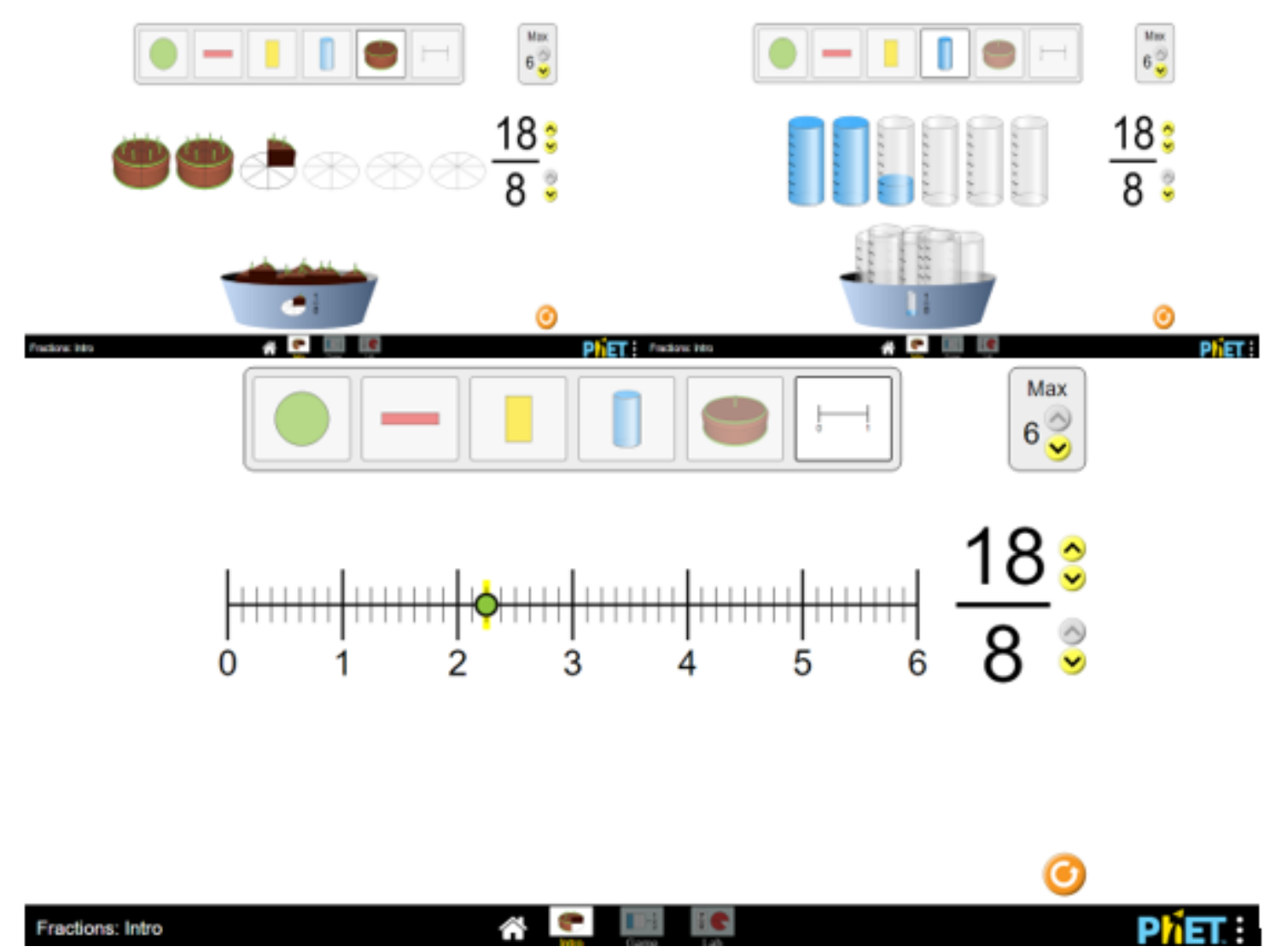

Gambar 7. Percobaan-percobaan mengubah bentuk representasi dari pecahan

Hal lain yang dapat mereka lakukan adalah mengubah angka-angka yang ada pada simulasi tersebut dan melihat apa yang terjadi. Banyak hal yang dapat mereka lakukan dalam rangka mengekplorasi simulasi yang baru mereka lihat. Mereka akan menemukan bagaimana beberapa hal bekerja dan mereka juga dapat menemukan ide-ide yang dapat mereka lakukan kemudian. Dalam masa ini siswa membangun kepercayaan diri mereka untuk dapat mengontrol simulasi tersebut.

Hindari memberikan petunjuk secara eksplisit kepada mereka tentang bagaimana mengoperasikan simulasi tersebut. Hindari arahan seperti "Ubah angka pada simulasi tersebut". Arahan yang dapat dilakukan adalah seperti "Eksplorasi simulasi tersebut dan cari tahu bagaimana kalian dapat menggambarkan bentuk pembagian $1: 2$ atau pecahan 1/ 2". Pekins (2012) menyebutkan bahwa Ketika siswa diminta secara eksplisit dalam kegiatan tersebut untuk mengontrol sesuatu atau menggunakan atau tidak menggunakan sesuatu, siswa cenderung untuk memfokuskan mengikuti arahan tersebut, terkadang secara "lurus". Hal ini dapat menghambat eksplorasi dan pembelajaran dari simulasi tersebut.

Selanjutnya, berikan waktu untuk siswa mendemonstrasikan apa yang mereka temukan kepada temantemannya yang lain. Guru dapat memfokuskan terhadap apa yang mereka pelajari dari simulasi tersebut. Hal tersebut juga dapat membentuk lingkungan yang kolaboratif di mana para siswa dapat membantu satu sama lain mengeksplorasi dan mengembangkan ide dan bahkan saling membantu dalam memecahkan masalah.

Langkah kedua: permainan dan tantangan. Di era digital saat ini, Sebagian besar siswa memiliki kecenderungan kuat menyukai permainan yang di dalamnya terdapat tantangan-tantangan. PhET Simulation menyediakan bentuk "permaianan" yang dapat dilakukan siswa di kelas, setelah siswa memahami konsep dari pecahan dan juga memahami cara kerja dari simulasi tersebut. Gambar di bawah ini menunjukkan tampilan dari permainan yang berhubungan dengan konsep pecahan. Perhatikan tampilan antar muka PhET simulation untuk permainan dalam topik pecahan. 


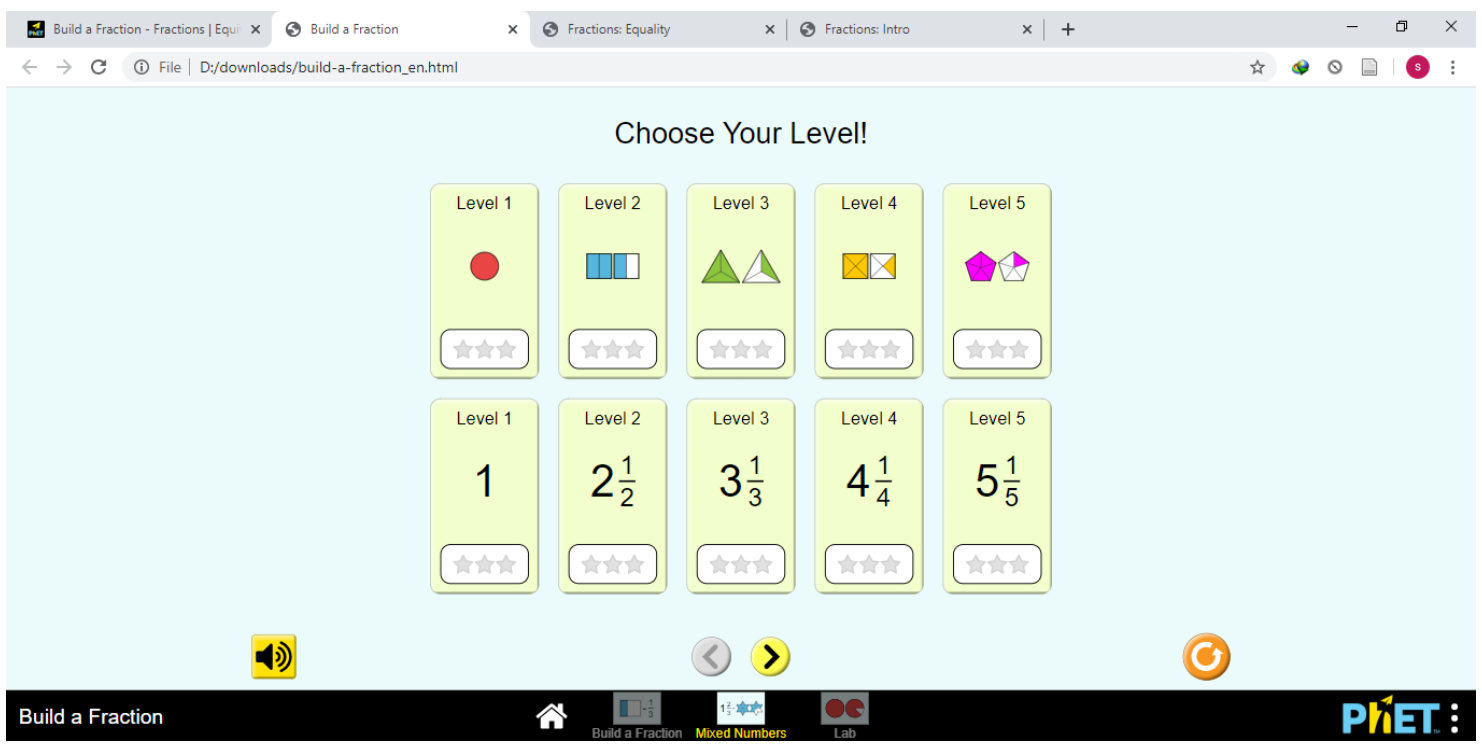

Gambar 8. Permainan dalam PhET Simulation terkait pecahan

Dalam permainan tersebut disediakan beberapa level atau tingkat kesulitan yang dapat dipilih siswa sesuai dengan minat dan kemampuannya. Terdapat 5 level dengan 2 macam kategori. Kategori yang pertama adalah permainan mencari deskripsi gambar yang pecahannya telah tersedia, kemudian memasangkannya. Untuk lebih jelasnya, perhatikan gambar 9 di bawah ini.

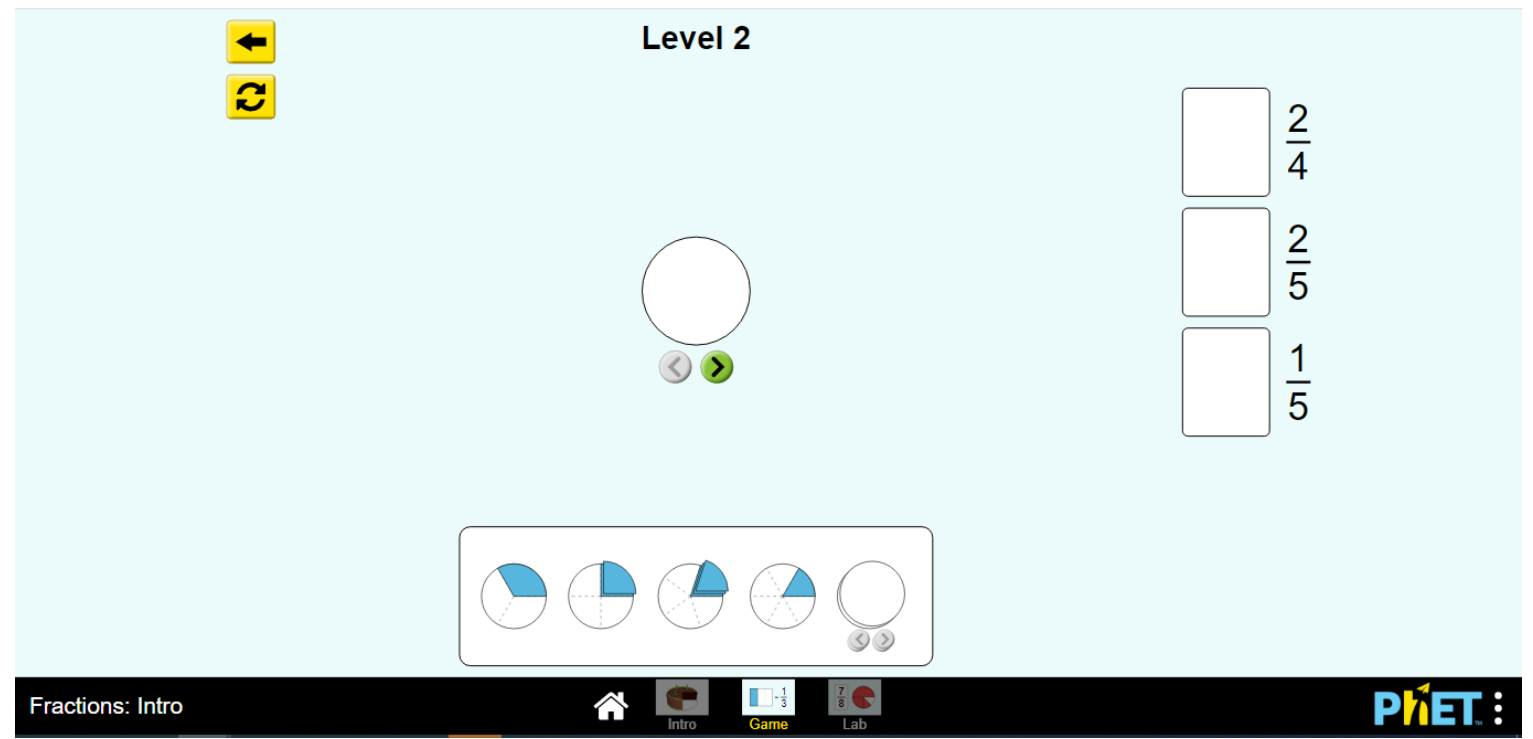

Gambar 9. Permainan dalam PhET simulation Kategori 1 untuk pecahan

Adapun kategori yang kedua adalah permainan mencari pecahan yang gambarnya telah diberikan kemudian memasangkannya. Tampilan dari permainan kategori tersebut dapat dilihat pada gambar 10. Dapat dilihat bahwa permainan tersebut merupakan permainan yang cukup sederhana, namun hal tersebut dapat mewujudkan tujuan dari pembelajaran ini. Dari permainan ini dapat dibangun kreatifitas dari siswa serta mengetahui tingkat pemahaman siswa terkait materi pecahan maupun pemahamam siswa dalam menggunakan simulasi ini. Permainan tersebut dapat menghasilkan produktifitas serta keterlibatan siswa dalam pembelajaran. Melalui rangkaian kegiatan terarah tersebut, akan meningkatkan ketertarika siswa dalam proses pembelajaran, khususnya dalam materi pecahan. Hal lain yang dapat diperoleh adalah keterlibatan siswa dalam proses belajar yang cukup tinggi. Siswa tidak hanya menjadi pendengar yang baik saja, tetapi juga dapat bereksplorasi dengan hal yang mereka dapatkan. 


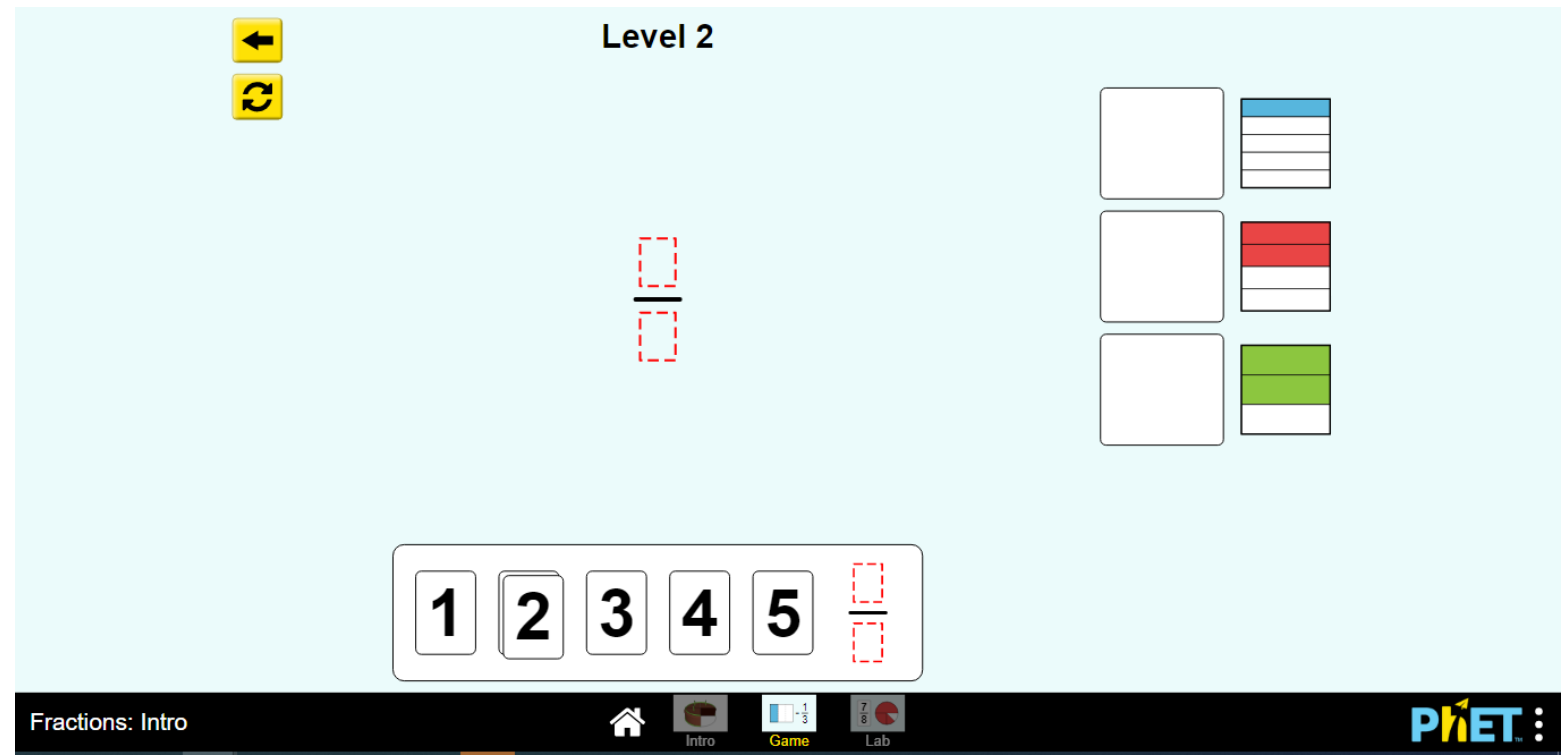

Gambar 10. Permainan dalam PhET simulation Kategori 2 untuk pecahan

Selain dari dua fasiliatas yang telah disebutkan di atas, terdapat satu lagi fasilitas yang disediakan oleh $\mathrm{PhET}$ simulation. Fitur tersebut adalah fitur lab yang dapat digunakan untuk mengeksplorasi lebih dalam lagi, khususnya untuk materi terkait pecahan. Pada langkah ini, guru dapat menciptakan tantangan yang menumbuhkan produktifitas siswa serta siswa dapat diajak untuk menemukan hal-hal baru. Tantangan tersebut dapat dibuat yang sejalan dengan tujuan pembelajaran ini dan dibuat dengan pemikiran serta "reasoning". Tantangan yang dapat dilakukan diantaranya dapat dalam bentuk " Temukan cara...., “ Temukan cara terbaik untuk...", dan lain sebagainya (perkins, 2012).

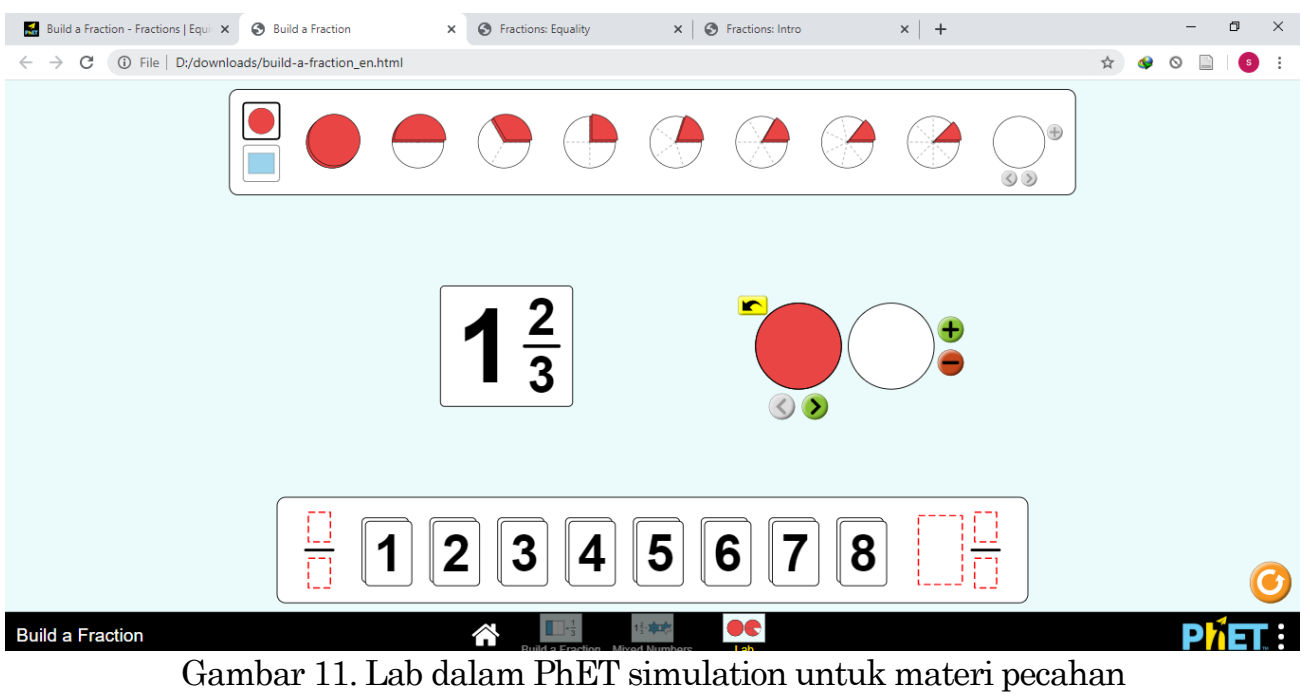

Langkah yang dapat dilakukan oleh guru adalah dengan mengasah kreatifitas mereka terkait apa yang dapat mereka lakukan dengan pecahan tersebut. Salah satu contonya misalkan membuat pecahan yang lebih tinggi, misalnya $12 / 3$. Mereka dapat melakukan representasi dari gambar ke angka atau angka ke gambar. Di sini siswa dapat dilatih untuk lebih kreatif dan produktif lagi.

\section{Simpulan}

PhET Simulation merupakan alat bantu atau media yang dapat digunakan oleh guru untuk membuat kegiatan belajar matematika, khususnya untuk materi pecahan, menjadi lebih menarik. Dengan PhET Simulation, dapat meningkatkan kemampuan eksplorasi siswa serta membuat siswa lebih tertarik terhadap materi tersebut. PhET simulation memberikan media untuk siswa dapat belajar, khususnya dalam hal ini 
belajar matematika dalam materi pecahan, dengan cara yang tidak membosankan. PhET simulation juga dapat meningkatkan ketertarikan serta keterlibatan siswa dalam proses belajar mengajar. Siswa menjadi tertantang untuk melakukan eksplorasi dari hasil pembelajaran yang telah dilakukannya. Dengan meningkatnya ketertarikan serta keterlibatan siswa dalam proses belajar mengajar, akan memudahkan siswa dalam memahami materi yang dipelajari.

\section{Daftar Pustaka}

1. C.E. Wieman, W.K. Adams \& K.K. Perkins, Science, 322, 682-683 (2008)

2. F.C. Permana, AC Padmasari, S. Sylviani, Rancang Bangun Aplikasi Pendeteksi Jenis Golongan Darah Berdasarkan Konsep Kepercayaan Rakyat Jepang (Minkan Shinko), Edsence: Jurnal Pendidikan Multimedia 1 (1), 25-34, 2019

3. Katherine Perkins, Emily Moore, Noah Podolefsky, Kelly Lancaster, and Christine Denison, Towards researchbased strategies for using PhET simulations in middle school physical science classes, AIP Conf. Proc. 1413, 295 (2012); doi: 10.1063/1.3680053

4. Sisilia Sylviani, Fahmi Candra Permana, Dian Rinjani, Penggunaan Maple dalam Upaya Peningkatan Minat Siswa SMA dalam Pembelajaran Materi Integral, Edsence: Jurnal Pendidikan Multimedia 1 (2), 25-34, 2019

5. https://PhET.colorado.edu/ 